\title{
Ultrastructural features of the Bufo arabicus adrenal glands
}

\author{
Taher A. Ba-Omar \\ Biology Department, College of Science, Sultan Qaboos University, P.O.Box 36, \\ Muscat, PC 123, OMAN \\ taher@squ.edu.om
}

Adrenal glands are composed of two type of cells; cortical and chromaffin cells. In mammals, the two cells are arranged separately into an outer region, the cortex, is made up of the cortical cells and an inner region, the medulla, which is made up of chromaffin cells. In birds and amphibians, the two cells are arranged in cords or groups which intermingle with each other. The two types of cells originate from two different germ cell. The cortical cells originate from mesoderm whereas the chromaffin cells come from ectoderm in particular neural crest cells. Both cortical and chromaffin cells differ in their structures and functions.

The Bufo arabicus were collected and transported into the Biology Department, Sultan Qaboos University, OMAN. The frog were killed by pithing. Then they were dissected out for their adrenal glands. The adrenal glands are located within of the abdominal cavity and attached to the kidneys. The adrenal glands were fixed in Karnovsky buffered with sodium cacodylate to a $\mathrm{pH}$ of 7.4 for four hours and then cut into small pieces. The tissue were washed in cacodylate buffer and then post-fixed in 1\% aqueous solution of osmium tetroxide for 1 hour and dehydrated in a series of alcohol before embedding in Agar 100 resin. Semi and ultra-thin sections were cut using Reichert ultramicrotome. The semi-thin sections were stained with toluidine blue and the sections were examined using a Nikon 104 light microscope. The ultra-thin sections were stained with uranyl acetate and post-stained in lead citrate. They were examined under JEOL JEM -1230 TEM.

The ultra-thin sections of the Bufo arabicus show the ultrastructure of the adrenal glands. The two types of cells that are making up the adrenal glands, cortical and chromaffin cells, have a polygonal shape with polygonal nuclei. The cortical and chromaffin cells differ in their ultrastructural features. The cortical cells possess a large number of mitochondria, and show the presence of smooth endoplasmic reticulum (SER) and lipid droplets (Fig. 1). In contrast, the chromaffin cells are characterized by the presence of chromaffin granules which have variable sizes and shapes(Fig. 2). 


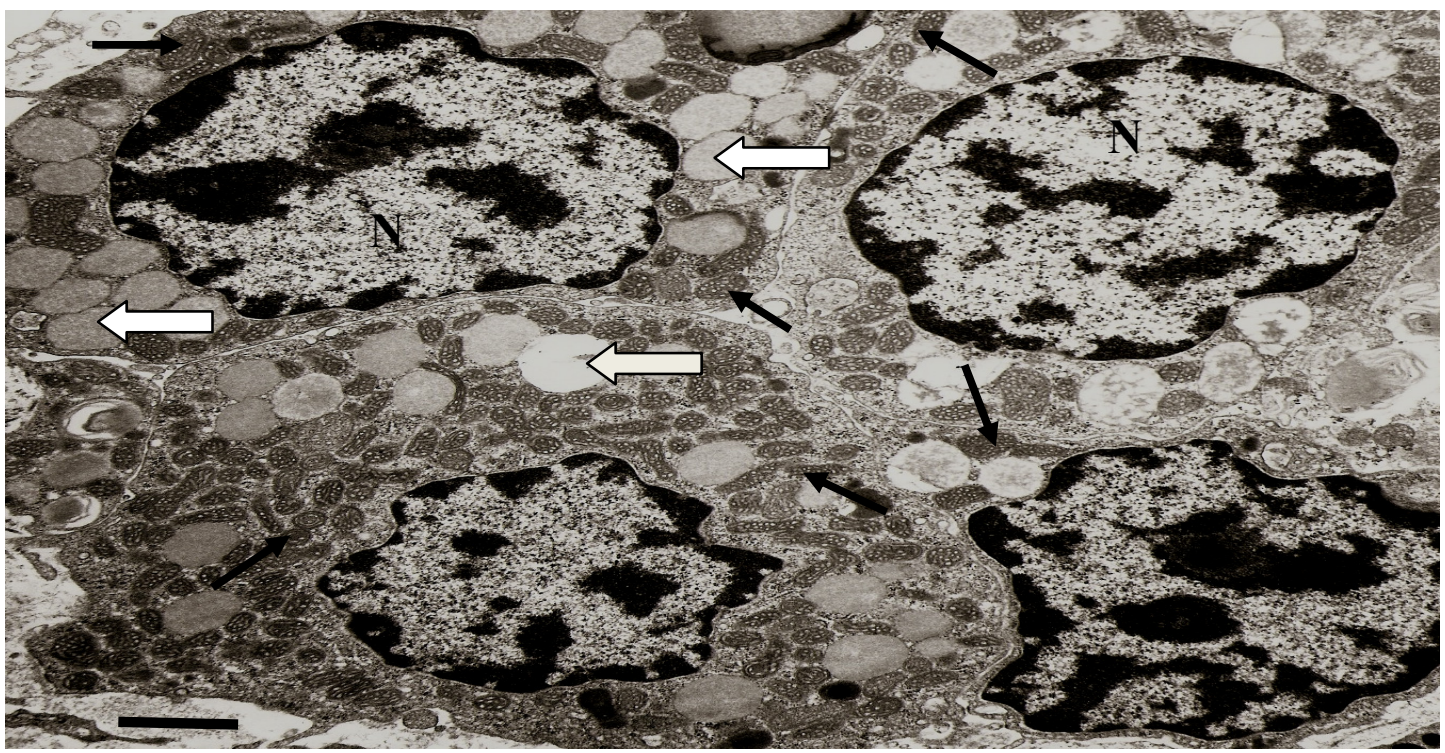

Fig 1. An electron micrograph of the cortical cells of the adrenal glands of the Bufo arabicus showing the ultrastructural features such as the mitochondria (small arrows), lipid droplets (large arrows). The nuclei are polygonal in shape $(\mathrm{N})$. Scale bar $=2.5 \mu \mathrm{m}$

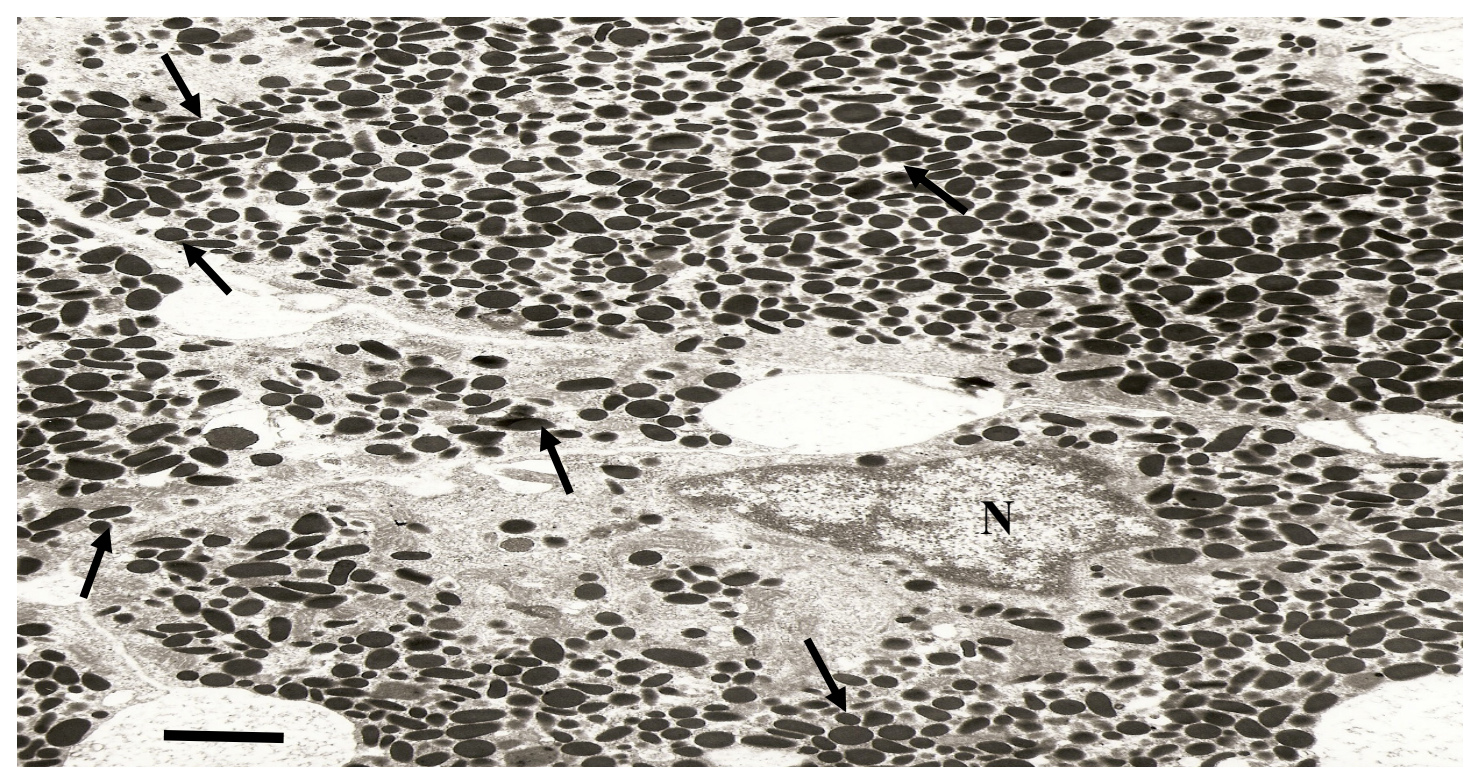

Fig.2. An electron micrograph of the chromaffin cells of the adrenal glands of the Bufo arabicus showing the ultrastructural features such chromaffin granules which have variable size and shape (arrows). The nuclei have polygonal shape (N). Scale bar $=2.5 \mu \mathrm{m}$ 